JNoP JURNAL INOVASI PEMBELAJARAN

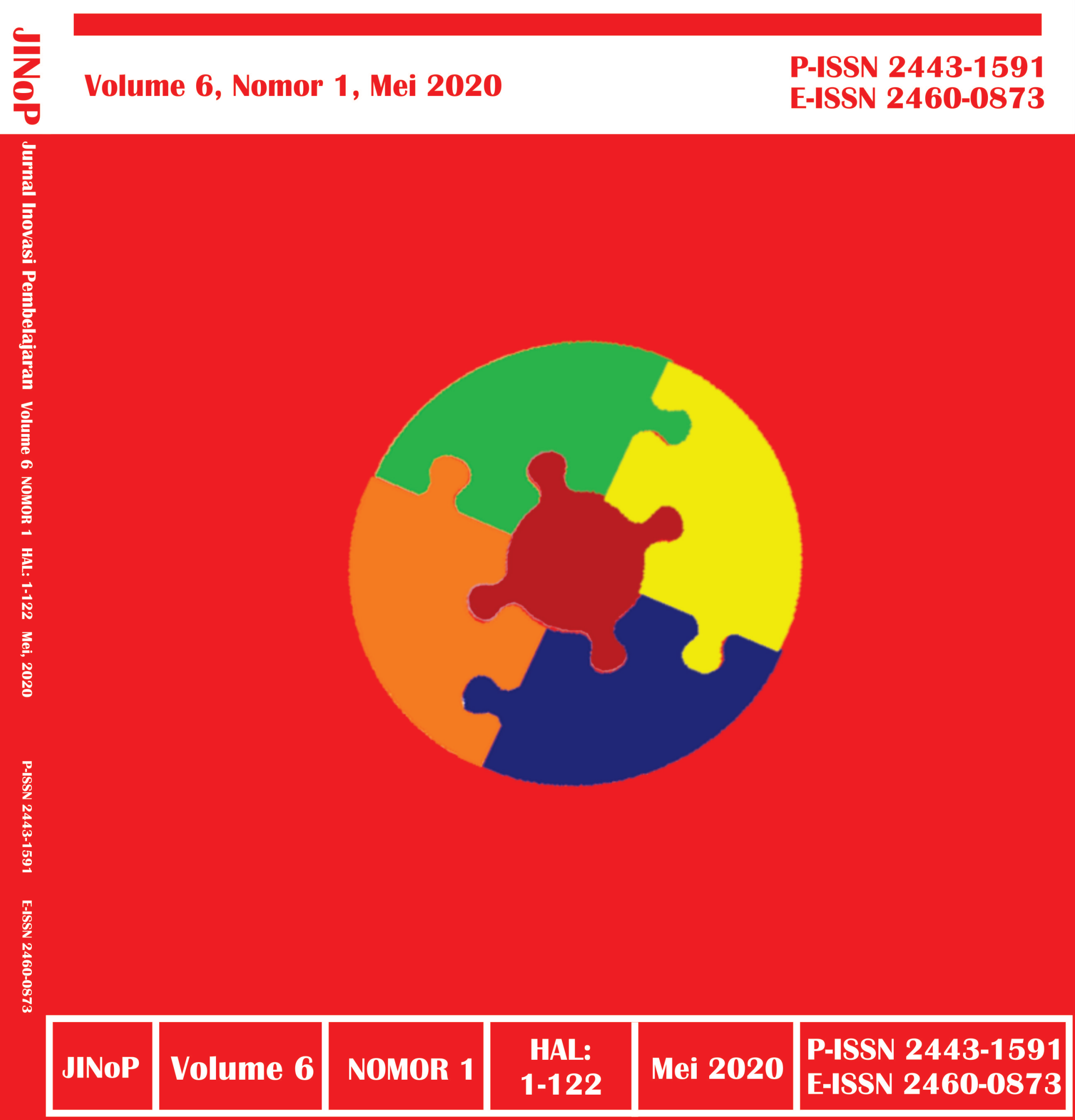


JINoP

Jurnal Inovasi Pembelajaran

Volume 6, Nomor 1, Mei 2020

JINoP (Jurnal Inovasi Pembelajaran) terakreditasi peringkat 3 berdasarkan Salinan Keputusan Direktur Jendral Penguatan Riset dan Pengembangan, Kementerian Riset, Teknologi, dan Pendidikan Tinggi, Nomor 30/E/KPT/2018, Tanggal 24 Oktober 2018. Akreditasi berlaku selama 5 (lima) tahun yaitu Volume 2 Nomor 2 Tahun 2016 sampai dengan Volume 7 Nomor 1 Tahun 2021. JINoP (Jurnal Inovasi Pembelajaran) diterbitkan dua kali setahun pada bulan Mei dan November oleh Universitas Muhammadiyah Malang dalam satu volume ada 2 nomor. Berisi tulisan ilmiah hasil penelitian tentang inovasi pembelajaran mulai dari pendidikan dasar sampai perguruan tinggi. Untuk Jurnal Online dapat diakses dilaman : http://ejournal.umm.ac.id/index.php/jinop/

\section{Editor In Chief}

Dr. Sugiarti, M.Si.

\section{Assosiate/Handling Editor}

Prof. Dr. Yus Mochamad Cholily, M.Si

\section{Editorial Board}

Prof. Dr. Burhan Nurgiyantoro, M.Pd.

Prof. Drs. Safnil, M.A., Ph.D.

Dwi Poedjiastutie, M.A., Ph.D.

Prof. Dr. Kokom Komalasari, M.Pd.

Dr. Prima Gusti Yanti, M.Hum.

Adityo, M.A.

\section{Mitra Bestari}

Dr. Somakim, M.Pd. (UNSRI)

Dr. Trisakti Handayani, M.M. (UMM)

Prof. Dr. Wahyudi Siswanto, M.Pd.(UM)

Dr. Baiduri, M.Si (UMM)

Prof. Dr. Endang Widi Winarni (UNIB)

Dra. Sri Wahyuni, M.Kes (UMM)

Nina Inayati, M.Ed. (UMM)

\section{Managing Editor}

Nur Adeputra, S.Pd.

Alamat Penyunting dan Tata Usaha

Kantor JINoP (Jurnal Inovasi Pembelajaran) Ruang 614

Jl. Raya Tlogomas 246 Malang 65144, Telp. (0341) 464318; Faksimile (0341) 460782

Pos-el : jinopfkip@gmail.com dan jinopfkip@umm.ac.id

Penyunting menerima sumbangan tulisan dari guru dan dosen yang belum pernah dimuat dalam media lain. Naskah ditulis dalam kertas A4 spasi satu antara 10-15 halaman, sesuai dengan format yang tercantum pada halaman belakang ("Petunjuk Penulisan artikel JINoP"). Penulis akan mendapatkan nomor bukti penerbitan sebanyak 2 eksemplar. 


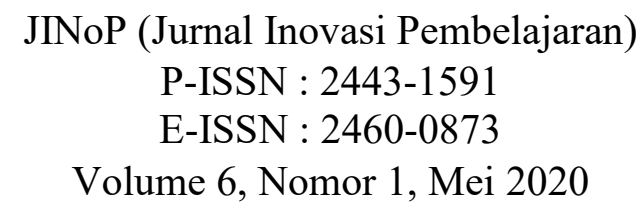

\section{DAFTAR ISI}

Implementasi Model Pembelajaran React dan Tinjauannya Terhadap Kemampuan $1-11$ Kolaboratif Mahasiswa Marhan Taufik, Siti Khoiruli Ummah, Alfiani Athma Putri Rosyadi

Peningkatan Keterampilan Menulis Puisi Menggunakan Model Bengkel Sastra Melalui Media Kotak Gambar Ajaib

Vera Krisnawati dan Nila Mega Marahayu

Pembelajaran Klasifikasi Kladogram Dengan Metode Taksimetri Untuk Mempelajari Kekerabatan Tanaman Genus Tillandsia \& Neoregelia

Fendy Hardian Permana, Nurwidodo, Lise Chamisijatin, Siti Zaenab, Yuni Pantiwati, Dwi Sulistiarini

Kompetensi Mahasiswa Pada Pembelajaran Matematika Menggunakan Geometer's Sketchpad dengan Authentic Assessment

Mohammad Syaifuddin, Reni Dwi Susanti, Rizal Dian Azmi

Covid-19 dan E-Learning: Perubahan Strategi Pembelajaran Sains dan Lingkungan di SMP

Ilmi Zajuli Ichsan, Henita Rahmayanti, Agung Purwanto, Diana Vivanti Sigit, Edi Kurniawan, Aryani Kadarwati Dewi, Nina Wirdianti, Farah Muthi Hermawati, Giry Marhento

Pengembangan Perangkat Pembelajaran Berbasis Praktikum Inkuiri Untuk Mata Pelajaranmenganalisis Rangkaian Listrik

Oriza Candra, Uslmeldi, Doni Tri Putra Yanto, Femypadillah Ismanto

Membangun Karakter Siswa Sekolah Dasar Melalui Praktek Pola Asuh Orang Tua Berdasarkan Genetic Personality

Karnawi Kamar, Masduki Asbari, Agus Purwanto, Wakhida Nurhayati, Eva Agistiawati, Rachma Nadhila Sudiyono

Peningkatan Aktivitas dan Kemampuan Menulis Surat Lamaran Pekerjaan Melalui Metode Sibomber Berbantuan Kuis Interaktif pada Peserta Didik Kelas I-4 SMA Negeri 3 Malang

Binti Ngafifatul Maidah, Sugiarti, Basuki Agus Priyana Putra.

Penggunaan Instrumen Diagnostik Two-Tier Untuk Menganalisis Miskonsepsi 101-112 Asam Basa Siswa SMA dan MA

Achmad Yandi Rahmatul Fajri, Salamah Agung, Nanda Saridewi

Pengembangan LKPD Berorientasi Metakognisi di SD Muhammadiyah 5 Bumiaji Delora Jantung Amelia, Ichsan Anshory A.M., Setiya Yunus Saputra 
